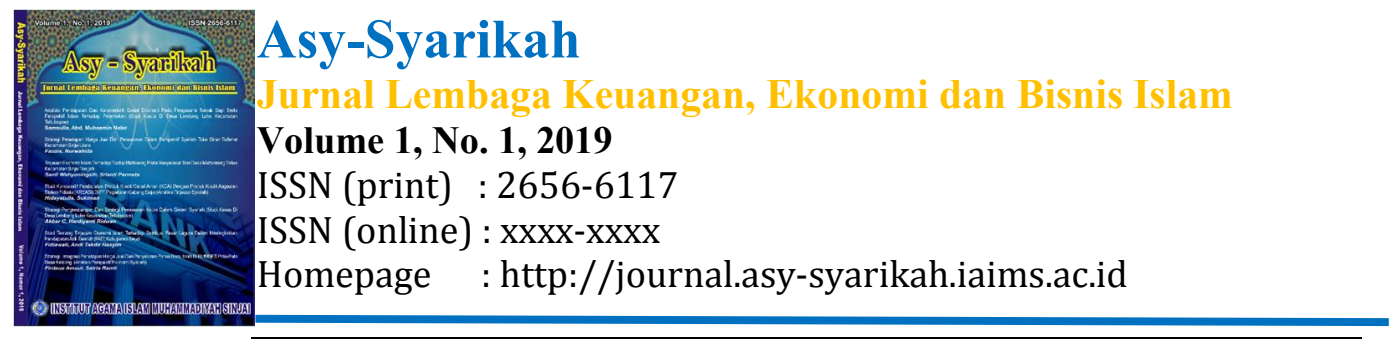

\title{
STRATEGI PENETAPAN HARGA JUAL DAN PENAWARAN DALAM PERSPEKTIF SYARIAH TOKO SINAR RAHMAT KECAMATAN SINJAI UTARA
}

\author{
Fauzia, Nurwahida \\ Institut Agama Islam Muhammadiyah Sinjai \\ E-mail/Tlp:nurwahidarusdin@gmail.com/082395174403
}

\begin{abstract}
Abstrak
Penelitian ini merupakan penelitian kualitatif yaitu jenis penelitian yang menghasilkan penemuan-penemuan yang tidak dapat dicapai dengan menggunakan prosedur statistik atau dengan cara-cara kuantifikasi. Penelitian kualitatif dapat menunjukkan kehidupan masyarakat, sejarah, tingkah laku, fungsionalisasi organisasi, pergerakan sosial dan hubungan kekerabatan. Pendekatan yang digunakan dalam penelitian ini adalah pendekatan naturalistic yaitu penelitian yang dilakukan dalam latar yang alamiah, bukan hasil manipulasi. Data penelitian diperoleh melalui wawancara dan dokumentasi dengan menggunakan instrumen pedoman wawancara. Hasil penelitian menunjukkan bahwa: (1)Strategi penetapan harga jual yang dilakukan oleh Toko Sinar Rahmat dengan cara yaitu, strategi perbedaan harga jual dengan menerapkan harga yang relatif murah, dengan kualitas barang yang sama dengan yang lain karena ingin mempunyai image harga yang baik dimata konsumen. Toko Sinar Rahmat menerapkan harga yang relatif murah dengan tujuan, agar harga mudah diingat oleh konsumen dan agar harga lebih unggul dari harga lain. (2)Penawaran dalam perspektif syariah, yaitu penawaran yang dilakukan dengan sewajarnya saja. Antara pihak penjual dan pihak pembeli, merasa tidak ada saling yang dirugikan satu sama lain. Dalam perspektif ekonomi islam, manusia di injeksi dengan norma moral islam sehingga nafsu untuk memenuhi keinginannya tidak selalu dipenuhi. Karena keinginan senantiasa dikaitkan dengan norma moral islam yang selalu menemaninya kemana saja dan dimana saja. Karena itu, semua barang yang ditawarkan mencerminkan kebutuhan sesuai dengan syariah itu sendiri.
\end{abstract}

Kata kunci: Strategi Penetapan Harga, Penawaran Dalam Perspektif Syariah.

\section{Pendahuluan}

Manusia adalah khalifah Allah dimuka bumi. Islam memandang bahwa bumi dengansegala isinya merupakan amanah Allah kepada sang khalifah agar dipergunakan sebaik-baiknya bagi kesejahteraan manusia. Untuk mencapai tujuan suci ini, Allah SWT telah memberikan aturan hidup melalui petunjuk Rasul-Nya. Petunjuk tersebut dinamakan Ad-dinul Islam (agama islam).

Wujud kepentingan ekonomi bersama merupakan suatu fakta yang tidak dapat ditolak. Meningkatnya kadar kemakmuran secara menyeluruh, meningkatnya daya beli disamping terciptanya permintaan dan selanjutnya bertambahnya kapasitas produksi 


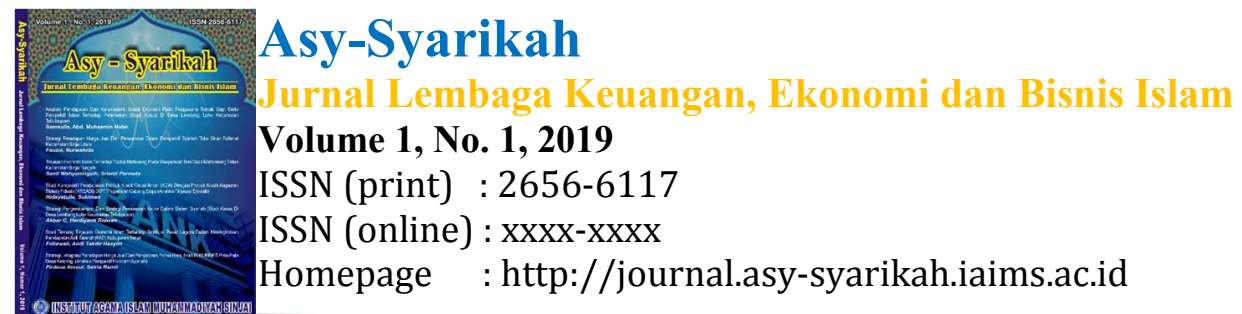

merupakan kepentingan yang sama-sama diinginkan oleh setiap individu, dan juga oleh pengusaha.

Pemahaman islam mengajarkan bahwa merupakan suatu kewajiban bagi setiap muslim untuk berusaha semaksimal mungkin melaksanakan semua syariah (aturan) islam disegala aspek kehidupan, termasuk dalam pencaharian kehidupan ekonomi. Demikian pula aspek ekonomi islam yang merupakan bagian ilmu sosial, tidak lepas dari konsepkonsep islam yang harus dilaksanakan dalam bidang tersebut. Kajian ekonomi islam salah satunya mencakup aspek muamalah,dengan berlandaskan pada Al-Qur'an dan AsSunnah. Ekonomi islam diikat dengan nilai iman, akhlak dan moral etik bagi setiap pelaku aktivitas ekonomi.

Muamalah dalam arti luas yaitu aturan-aturan (hukum-hukum) Allah untuk mengatur manusia dalam kaitannya dengan urusan duniawi dalam pergaulan sosial. Sedangkan, muamalah dalam arti sempit yaitu semua akad yang membolehkan manusia saling menukar manfaatnya dengan cara-cara dan aturan-aturan yang telah ditentukan Allah dan manusia wajib menaati-Nya.

Khusus dalam bidang perekonomian, tujuan syariah islam adalah menciptakan keadilan dan kesejahteraan dalam berbisnis dan berusaha. Keadilan disini dipahami oleh seorang muslim bahwa ketika berbisni atau bermuamalah harus menaati syariah islam (hukum Allah) dan mengikuti petunjuk Rasulullah SAW., bukan menurut hawa nafsunya atau dengan cara batil demi mengejar keuntungan yang sebesar-besarnya.

Masalah harga atau lebih tepatnya harga keseimbangansangat menentukan keseimbangan perekonomian, sehingga hal inipun telah dibahas dalam ekonomi islam. Dalam konsep ekonomi islam, harga ditentukan oleh keseimbangan permintaan dan penawaran. Keseimbangan ini terjadi bila antara penjual dan pembeli bersikap saling merelakan. Kerelaan ini ditentukan oleh penjual dan pembeli dalam mempertahankan kepentingannya atas barang tersebut. Jadi, harga ditentukan oleh kemampuan penjual untuk menyediakan barang yang ditawarkan kepada pembeli, dan kemampuan pembeli untuk mendapatkan harga tersebut dari penjual.

Dalam sejarah islam masalah penentuan harga dibebaskan berdasarkan persetujuan khalayak masyarakat. Rasulullah SAW. sangat menghargai harga yang terjadi, karena mekanisme pasar yang bebas dan menyuruh masyarakat muslim untuk mematuhi peraturan ini. Beliau menolak untuk membuat kebijakan penetapan harga manakala tingkat harga pada saat itu tiba-tiba naik. Sepanjang kenaikan terjadi karena permintaan 


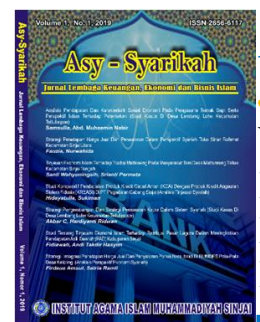

Asy-Syarikah

Jurnal Lembaga Keuangan, Ekonomi dan Bisnis Islam

Volume 1, No. 1, 2019

ISSN (print) : 2656-6117

ISSN (online) : xxxx-xxxx

Homepage : http://journal.asy-syarikah.iaims.ac.id

dan penawaran yang murni dan wajar, yang tidak dipaksa atau tekanan tertentu (tekanān monopolistik dan monopsonistik).

Pemasaran adalah suatu upaya untuk menciptakan dan menjual produk kepada berbagai pihak dengan maksud tertentu. Kemudian dibeli oleh mereka yang memiliki kebutuhan melalui suatu pertukaran. Pemasaran berusaha menciptakan dan mempertukarkan baik berupa barang ataupun jasa kepada konsumen dipasar. Penciptaan produk tersebut didasarkan pada kebutuhan dan keinginan pasar. Dalam islam telah diatur mengenai cara bermuamalah bagi seorang muslim. Dalam jual beli kaitannya dengan penentuan harga, islam memperbolehkan jual beli dan melarang riba. Hal tersebut tertuang dalam QS. Al-Baqarah (2): 275 sebagai berikut :

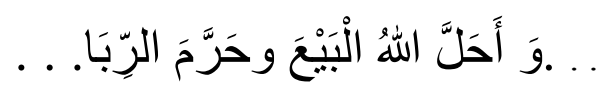

Artinya:"Padahal Allah Telah menghalalkan jual beli dan mengharamkan riba..."

Penetapan harga menurut pandangan islam, tidak boleh ada unsur riba di dalamnya sebagaimana telah tertuang dalam ayat diatas. Bagi pedagang tidak boleh meraup keuntungan yang sebesar-besarnya dengan menaikkan harga. Pedagang hanya boleh meraup untung yang sewajarnya saja sebagai pengganti atas jasanya.

Berdasarkan pengamatan penulis di Toko Sinar Rahmat harga jual yang ditentukan oleh penjual terbilang terjangkau. Namun, harga tersebut masih bisa ditawar dibawah harga yang telah ditentukan oleh penjual. Hal tersebut membuat masyarakat banyak yang berminat untuk membeli aksesoris di Toko Sinar Rahmat Produk yang ditawarkan pun memiliki harga yang berbeda-beda sesuai dengan jenisnya. Padahal, masih banyak pelanggan tetap menawar produk dibawah harga yang telah ditentukan penjual. Namun, usaha ini tetap bertahan dipasaran. Dengan kata lain, meski menjual produk dengan harga yang telah ditentukannya dan tetap menerima penawaran harga dari pembeli, usaha ini tetap bertahan.Karena, harga jual yang ditetapkan merupakan harga yang bisa dijangkau oleh masyarakat.

Oleh karena itu, penulis tertarik melakukan penelitian ditempat ini dengan judul "Strategi Penetapan Harga Jual dan Penawaran Dalam Perspektif Syariah Toko Sinar Rahmat Kecamatan Sinjai Utara."

Berdasarkan latar belakang yang telah penulis paparkan di atas, maka dapat dirumuskan permasalahan sebagai berikut: 


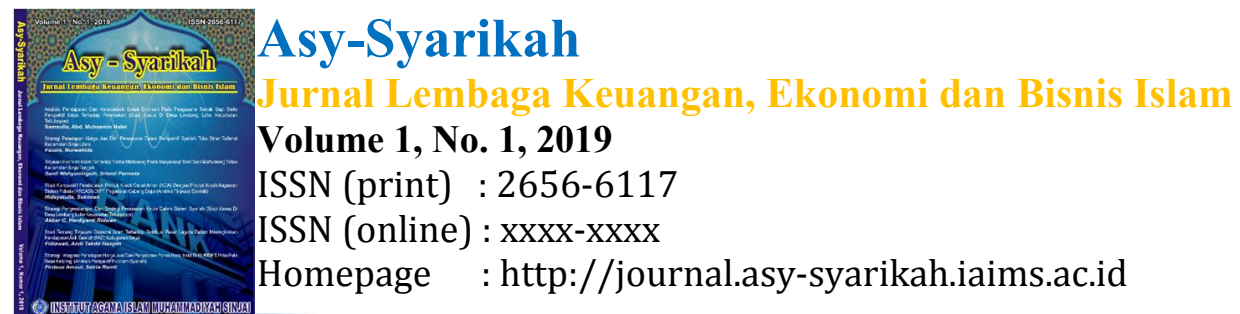

a. Bagaimana strategi penetapan harga jual di Toko Sinar Rahmat Kecamatan Sinjai Utara?

b. Bagaimana pandangan syariah tentang penawaran di Toko Sinar Rahmat Kecamatan Sinjai Utara?

\section{Tinjauan Pustaka}

\subsection{Pengertian Strategi}

Strategi adalah langkah-langkah yang harus dijalankan oleh suatu perusahaan untuk mencapai tujuan. Kadang-kadang langkah yang harus dihadapi terjal dan berliku-liku, namun ada pula langkah yang relatif mudah. Disamping itu, banyaknya rintangan atau cobaan yang dihadapi untuk mencapai tujuan. Oleh karena itu setiap langkah harus dihadapi dengan hati-hati dan terarah.

a. Pengertian Harga jual

Harga merupakan sejumlah nilai yang harus dibayar oleh konsumen untuk membeli barang atau jasa yang ditawarkan. Harga jual suatu produk perlu ditetapkan, dimaksudkan untuk memperoleh laba. Penentuan harga menjadi sangat penting, mengingat harga merupakan salah satu penyebab laku tidaknya produk barang atau jasa yang ditawarkan.

b. Penetapan Harga Geografis

Penetapan harga geografis melibatkan perusahaan dalam memutuskan cara menetapkan harga produknya kepada pelanggan dalam lokasi-lokasi yang berbeda. Apakah perusahaan harus menetapkan harga yang lebih tinggi terhadap pelanggan yang jauh untuk menutupi biaya pengiriman yang lebih tinggi dengan resiko hilangnya usaha mereka? Atau apakah perusahaan harus menetapkan harga yang sama bagi semua pelanggan dimanapun mereka berada?

c. Potongan Harga dan Potongan Pembelian

Kebanyakan perusahaan akan memodifikasi harga dasar mereka untuk memberi hadiah kepada pelanggan untuk pembyaran awal, volume pembelian dan pembelian diluar musim. Penyesuaian harga ini disebut diskon dan potongan pembelian.

1) Diskon/ Potongan Kas

2) Diskon/ Potongan Jumlah

3) Diskon/ Potongan Fungsional

4) Diskon/ Potongan Musiman 


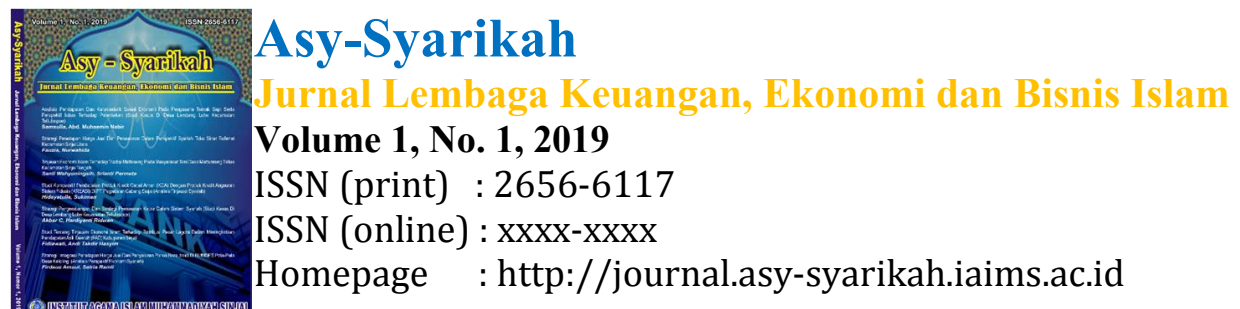

d. Penetapan Harga Dalam Pandangan Islam

Setelah perpindahan (hijrah) Rasulullah SAW. ke Madinah, maka beliau menjadi pengawas pasar (muhtasib). Pada saat itu Mekanisme Pasar, sangat dihargai. Salah satu buktinya yaitu Rasulullah SAW. menolak untuk membuat kebijakan dalam penetapan harga, pada saat itu harga sedang naik karena dorongan permintaan dan penawaran yang dialami.

Mekanisme penentuan harga dalam islam sesuai dengan Maqashid Al Syariah, yaitu merealisasikan kemaslahatan dan menghindari kerusakan diantara manusia. Seandainya Rasulullah saat itu langsung menetapkan harga maka akan kontradiktif dengan mekanisme pasar. Akan tetapi pada situasi tertentu, dengan dalih Maqashid al-syariah penentuan harga menjadi suatu keharusan dengan alasan menegakkan kemaslahatan manusia dengan memerangi distorsi pasar (memerangi mafsadah atau kerusakan yang terjadi dilapangan).

Konsep mekanisme pasar dalam islam dibangun atas prinsip-prinsip sebagai berikut:

a. Ar-Ridha, yakni segala transaksi yang dilakukan haruslah atas dasar kerelaan antara masing-masing pihak. Hal ini sesuai dengan QS. An-Nisa (4): 29, sebagai berikut:

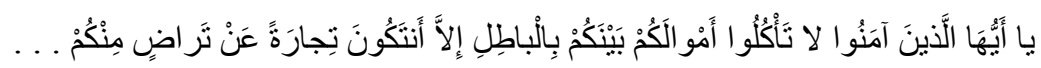

Artinya : Wahai orang-orang yang beriman! Janganlah kamu memakan harta sesamamu dengan jalan yang batil kecuali dengan jalan perniagaan yang berlaku suka sama suka diantara kamu. . .

Ayat tersebut diatas menjelaskan bahwa, manusia tidak boleh memakan harta sesamanya dengan jalan yang tidak benar. Dengan kata lain, manusia tidak boleh mendzalimi manusia lain untuk mendapatkan keuntungan yang lebih, kecuali dengan jalan perdagangan atas dasar suka sama suka antara kedua belah pihak.

b. Berdasarkan persaingan sehat. Mekanisme pasar akan terhambat bekerja jika terjadi penimbunan (ihtikar) atau monopoli. Monopoli setiap barang yang penahanannya akan membahayakan konsumen atau orang banyak.

c. Kejujuran, merupakan pilar yang sangat penting dalam islam. Islam melarang tegas melakukan kebohongan dan penipuan dalam bentuk apapun. Sebab, nilai kebenaran akan berdampak kepada pihak yang melakukan transaksi dalam perdagangan. 


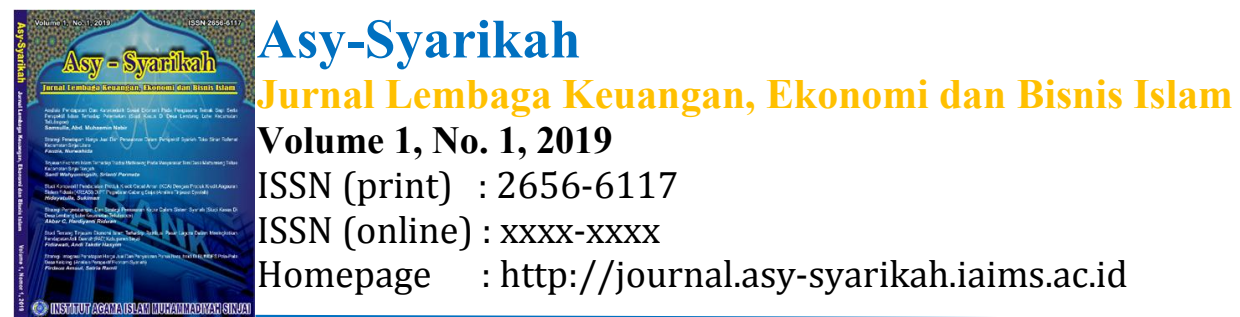

d. Keterbukaan serta keadilan. Pelaksanaan prinsip ini adalah transaksi dituntut untuk berlaku benar dalam pengungkapan kehendak dan keadaan yang sesungguhnya.

\subsection{Tinjauan Tentang Penawaran}

a. Pengertian Penawaran

Penawaran adalah jumlah barang atau jasa yang ditawarkan produsen pada berbagai tingkat harga pada suatu waktu tertentu. Artinya, produsen atau penjual menawarkan barangnya kepada konsumen dengan tingkat harga tertentu.

Penawaran suatu barang juga dipengaruhi oleh beberapa faktor yaitu :

1) Harga barang itu sendiri

2) Harga barang lain yang memiliki hubungan (barang pengganti atau barang pelengkap)

3) Teknologi yang digunakan

4) Harga input (ongkos produksi)

5) Tujuan perusahaan

b. Teori Penawaran Perspektif Syariah

Secara umum, tidak banyak perbedaan antara teori penawaran konvensional dengan islami sejauh hal itu dikaitkan dengan variabel atau faktor yang turut berpengaruh terhadap posisi penawaran. Bahkan bentuk kurva secara umum pada hakikatnya sama. Satu aspek penting yang memberikan suatu perbedaan dalam perspektif ini kemungkinan besar berasal dari landasan filosofi dan moralitas yang didasarkan pada premis nilai-nilai islam, yaitu :

1) Bahwa islam memandang manusia secara umum, apakah sebagai konsumen atau produsen, sebagai suatu objek yang terkait dengan nilai-nilai. Nilai-nilai yang paling pokok yang didorong oleh islam dalam kehidupan perekonomian adalah kesederhanaan, tidak silau dengan gemerlapnya kenikmatan duniawi (zuhud) dan ekonomis (iqtishad).

2) Norma-norma islam yang selalu menemani kehidupan manusia yaitu halal dan haram. Produk-produk dan transaksi pertukaran barang dan jasa tunduk kepada norma ini. Hal-hal yang diharamkan pada manusia itu pada hakikatnya adalah barang-barang atau transaksi-transaksi yang berbahaya bagi diri mereka dan kemaslahatannya. Namun demikian, bahaya yang ditimbulkan itu tidak selalu 


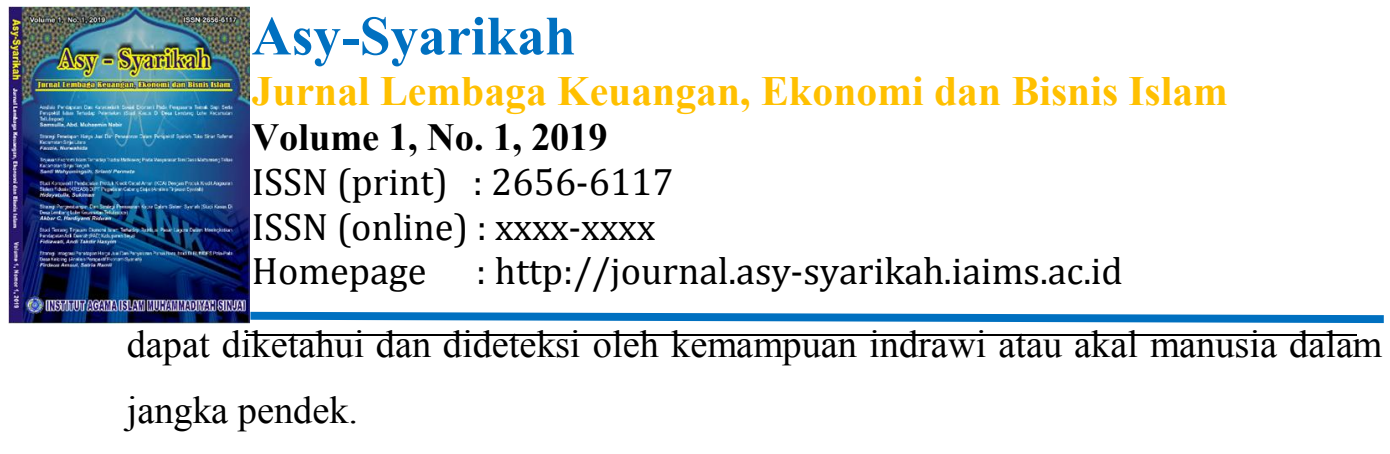

Dengan kedua batasan ini maka lingkup produksi dan pada gilirannya adalah lingkup penawaran itu sendiri dalam ekonomi islam menjadi lebih sempit dari pada yang dimiliki ekonomi konvensional. Dengan demikian terdapat dua penyaringan (filter) yang membuat wilayah penawaran dalam ekonomi islam menyempit yaitu filososfi kehidupan islam dan norma moral islam.

Adapun faktor-faktor penawaran dalam ekonomi islam adalah :

\section{a. Mashlahah}

Mashlahah berasal dari bahasa arab yang berarti memelihara tujuan syara' dan meraih manfaat atau menghindarkan kemudharatan. Pengaruh mashlahah terhadap penawaran pada dasarnya akan tergantung pada tingkat keimanan dari produsen. Jika jumlah mashlahah yang terkandung dalam barang yang diproduksi semakin meningkat maka produsen muslim akan memperbanyak jumlah produksinya.

b. Keuntungan

Keuntungan merupakan bagian dari mashlahah karena ia dapat mengakumulasi modal yang pada akhirnya dapat digunakan untuk berbagai aktivitas lainnya. Dengan kata lain keuntungan akan menjadi tambahan modal guna memperoleh mashlahah lebih besar lagi untuk mencapai falah (kesuksesan dan kemenangan dunia dan akhirat).

\section{Hasil Penelitianyang Relevan}

a. Skripsi Nur Aisyahyang berjudul "Analisis Mekanisme Penetapan Harga Jual Dalam Perspektif Prinsip-Prinsip Ekonomi Syariah (Studi Kasus di Toko Arafah Jl. Perjuangan Cirebon)". Adapun hasil dari penelitiannya adalah Mekanisme penetapan harga yang dilakukan oleh Toko Arafah dalam penggunaan mekanisme penetapan harga odd price atau harga ganjil sesuai dengan prinsip-prinsip ekonomi syariah yaitu merupakan mekanisme penetapan harga jual berbasis nilai keadilan dengan menetapkan harga yang wajar dan tidak mengambil keuntungan yang besar dan merupakan titik keseimbangan antara kekuatan permintaan dan penawaran yang disepakati secara sukarela oleh pembeli dan penjual dengan memperhatikan daya beli masyarakat dan kemampuan masyarakat dalam membeli.

b. Skripsi Sukarno Dewantoro yang berjudul "Strategi Penetapan Harga Pada PT Madubaru Bantul”. Adapun hasil penelitiannya adalah bahwa strategi harga yang 


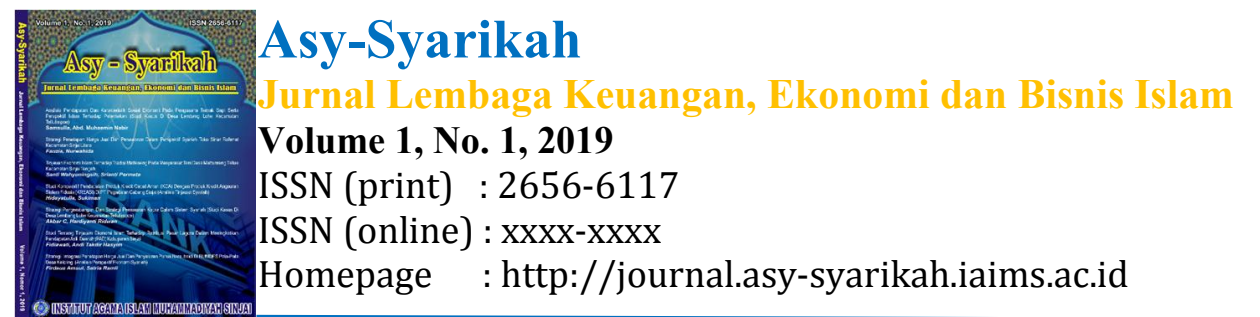

diterapkan pada PT Madubaru Bantul adalah PT Madubaru menerapkan strategi memposisikan produk melalui harga dan kualitas, karena PT Madubaru ingin produk gula pasir bisa menarik lebih banyak konsumen khususnya Yogyakarta dan Jawa Tengah sebagai perusahaan yang membuat berbagai produk gula pasir yang bermacam-macam ukuran maupun kemasan sehingga konsumen lebih mudah untuk memilih produk mana yang sesuai dengan kebutuhan mereka.

c. Skripsi Mariana Setyanwati Putri yang berjudul "Penetapan Harga Jual Produk (Studi Kasus Pada PT. Sari Husada Yogyakarta)". Adapun Hasil Penelitian adalah bahwa penetapan harga jual yang diterapkan yaitu, yang pertama menetapkan ROI yang diharapkan kemudian dengan menggunakan metode Cost Plus Pricing, penulis menghitung harga jual berdasarkan persentase Mark $U p$ yang ditentukan, dan langkah terakhir adalah menentukan harga jual produk dengan cara menambah persentase Mark Up pada harga pokok produk.

Berbeda dengan penelitian sebelumnya, penelitian ini berfokus pada strategi dalam menetapkan harga jual dan penawaran dalam pandangan syariah. Sedangkan, penelitianpenelitian diatas meneliti tentang Analisis Mekanisme Penetapan Harga Jual Dalam Perspektif Prinsip-Prinsip Ekonomi Syariah (Study Kasus di Toko Arafah), Strategi Penetapan Harga Pada PT Madubaru Bantul, dan Penetapan Harga Jual Produk (Studi Kasus Pada PT. Sari Husada Yogyakarta). Dengan demikian, maka terdapat sisi yang berbeda antara penelitian penulis dengan penelitian yang telah ada sebelumnya.

\section{Metode Penelitian}

\subsection{Jenis dan Pendekatan Penelitian}

Jenis penelitian dalam tesis ini meliputi kombinasi antara penelitian pustaka (library research) dan penelitian lapangan (field research) dengan metode kualitatif (qualitative method) yang dilakukan secara deskriptif analisis, karena penelitian ini memberikan gambaran tentang hasil penelitian dengan mendeskripsikan data-data aktual yang diperoleh di lapangan.

Pendekatan yang digunakan dalam penelitian ini adalah Pendekatan yang digunakan dalam penelitian ini adalah pendekatan naturalistic yaitu penelitian yang dilakukan dalam latar yang alamiah, bukan hasil manipulasi variabel yang dilibatkan. 


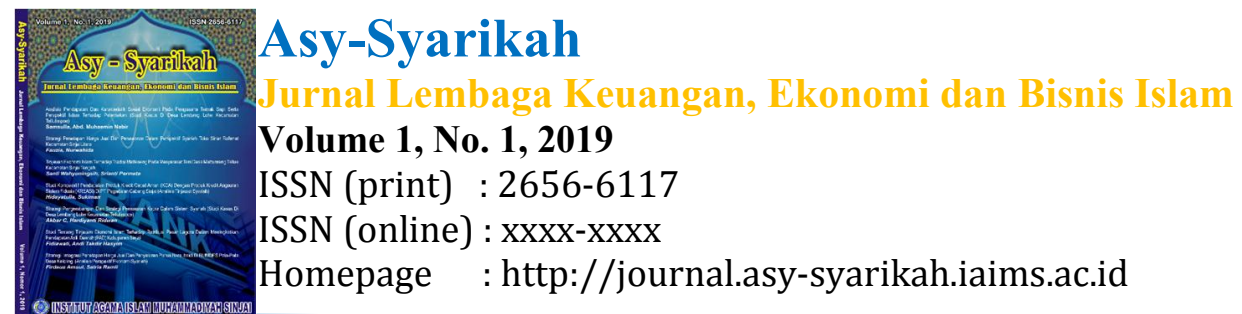

\subsection{Metode Pengumpulan Data}

Untuk memperoleh data-data lapangan, penulis menggunakan teknik pengumpulan data sebagai berikut :

a. Wawancara(Interview)

Wawancara adalah proses tanya jawab dalam penelitian yang berlangsung secara lisan dalam mana dua orang atau lebih bertatap muka mendengarkan secara langsung informasi-informasi atau keterangan-keterangan.

Wawancara ini digunakan untuk mendapatkan informasi tentang strategi dalam menetapkan harga jual dan penawaran perspektif syariah di Toko Sinar Rahmat.

b. Dokumentasi

Sejumlah besar fakta dan data tersimpan dalam bahan yang berbentuk dokumentasi. Biasanya berbentuk surat-surat, catatan harian, laporan, artefak, foto dan sebagainya. Menurut Sugiyono dikutip oleh Imam Gunawan menyatakan bahwa "dokumen merupakan catatan peristiwa yang sudah berlalu yang berbentuk tulisan, gambar, atau karya monumental dari seseorang”.

Dokumen disini mengacu pada material (bahan) seperti fotografi, video, film, memo, surat, diari, rekaman kasus klinis, dan sejenisnya yang dapat digunakan sebagai informasi suplemen.

\subsection{Instrumen Penelitian}

Berdasarkan dari jenis pengumpulan data yang digunakan penulis, maka bentuk instrumen yang digunakan adalah :

a. Pedoman wawancara adalah sejumlah pertanyaan yang diajukan kepada responden untuk mendapatkan informasi secara langsung.

b. Dokumen adalah sebuah alat yang digunakan untuk memperoleh informasi pelengkap seperti rekaman, video, foto dan sejenisnya yang tidak didapatkan melalui wawancara.

\subsection{Teknik Analisis Data}

Teknik analisis data adalah proses mencari dan menyusun secara sistematis data yang diperoleh dari hasil wawancara, catatan lapangan, dan dokumentasi, dengan cara mengorganisasikan data kedalam kategori, menjabarkan kedalam unit-unit, melakukan sintesa, menyusun kedalam pola, memilih mana yang penting dan yang akan dipelajari, dan membuat kesimpulan sehingga mudah dipahami oleh diri sendiri maupun orang lain. 


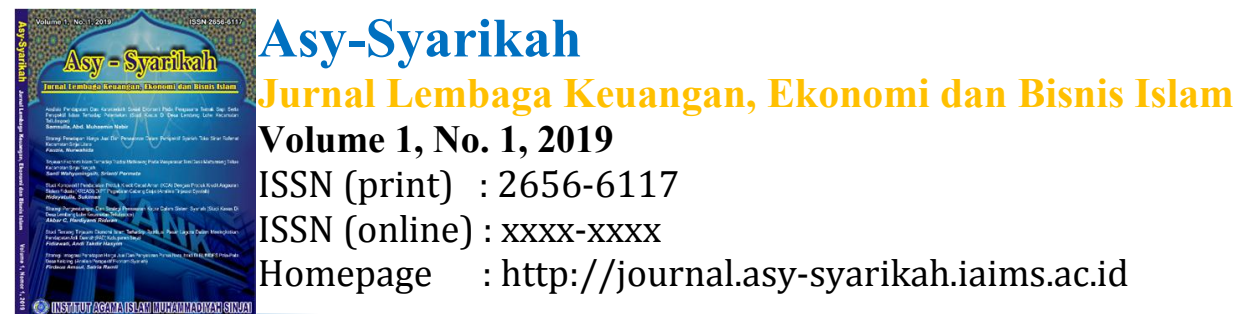

Adapun teknik analisis data yang digunakan dalam penelitian ini adalah teknik analisis data versi Miles dan Huberman sebagai berikut:

a. Data Reduction (Reduksi Data)

Mereduksi data berarti merangkum, memilih hal-hal yang pokok, memfokuskan pada hal-hal yang penting, dicari tema dan polanya. Dengan demikian data yang telah direduksi akan memberikan gambaran yang lebih jelas, dan mempermudah peneliti untuk melakukan pengumpulan data selanjutnya, dan mencarinya bila diperlukan.

b. Data Display (Penyajian Data).

Dalam penelitian kualitatif, penyajian data bisa dilakukan dalam bentuk uraian singkat, bagan, hubungan antar kategori, dan sejenisnya. Dengan mendisplay data, maka akan memudahkan untuk memahami apa yang terjadi, merencanakan kerja selanjutnya berdasarkan apa yang telah dipahami tersebut.

\section{c. Verification (Verifikasi Data)}

Langkah ketiga dalam analisis data kualitatif menurut Miles dan Huberman adalah penarikan kesimpulan dan verifikasi. Kesimpulan awal yang dikemukakan masih bersifat sementara, dan akan berubah bila tidak ditemukan bukti-bukti yang kuat dan mendukung pada tahap pengumpulan data berikutnya.

\section{Hasil Penelitian Dan Pembahasan}

Faktor yang menjadi pertimbangan Toko Sinar Rahmat dalam menentukan harga jual adalah keuntungan. Karena, harga akan selalu mengalami peningkatan setiap pendistribusian barang dari pabrik ke distributor, disalurkan ke pedagang besar, selanjutnya pengecer sebelum akhirnya diterima konsumen. Meski dengan menentukan harga jual yang tergolong murah, Toko Sinar Rahmat tetap meraup keuntungan.

Ada empat variabel yang digunakan untuk memperkenalkan produk yaitu :

a. Periklanan (Advertising), dengan periklanan citra produk dapat dibangun dalam jangka panjang, mengingat periklanan sangat luas jangkauannya. Cara ini dapat dilakukan di media cetak dan elektronik.

b. Penjualan Pribadi (Personal Selling), diperlukan tenaga penjual yang handal untuk meyakinkan calon pembeli mengenai karakteristik produk yang ditawarkan. Sistem ini akan tercipta suatu interaksi langsung antara pembeli dan penjual, sehingga penjual akan segera mengetahui reaksi pembeli mengenai produk tersebut.

c. Promosi Penjualan (Sales Promotion) sistem promosi ini memiliki sifat yang komunikatif dan dapat menciptakan tanggapan yang lebih kuat dan lebih cepat 


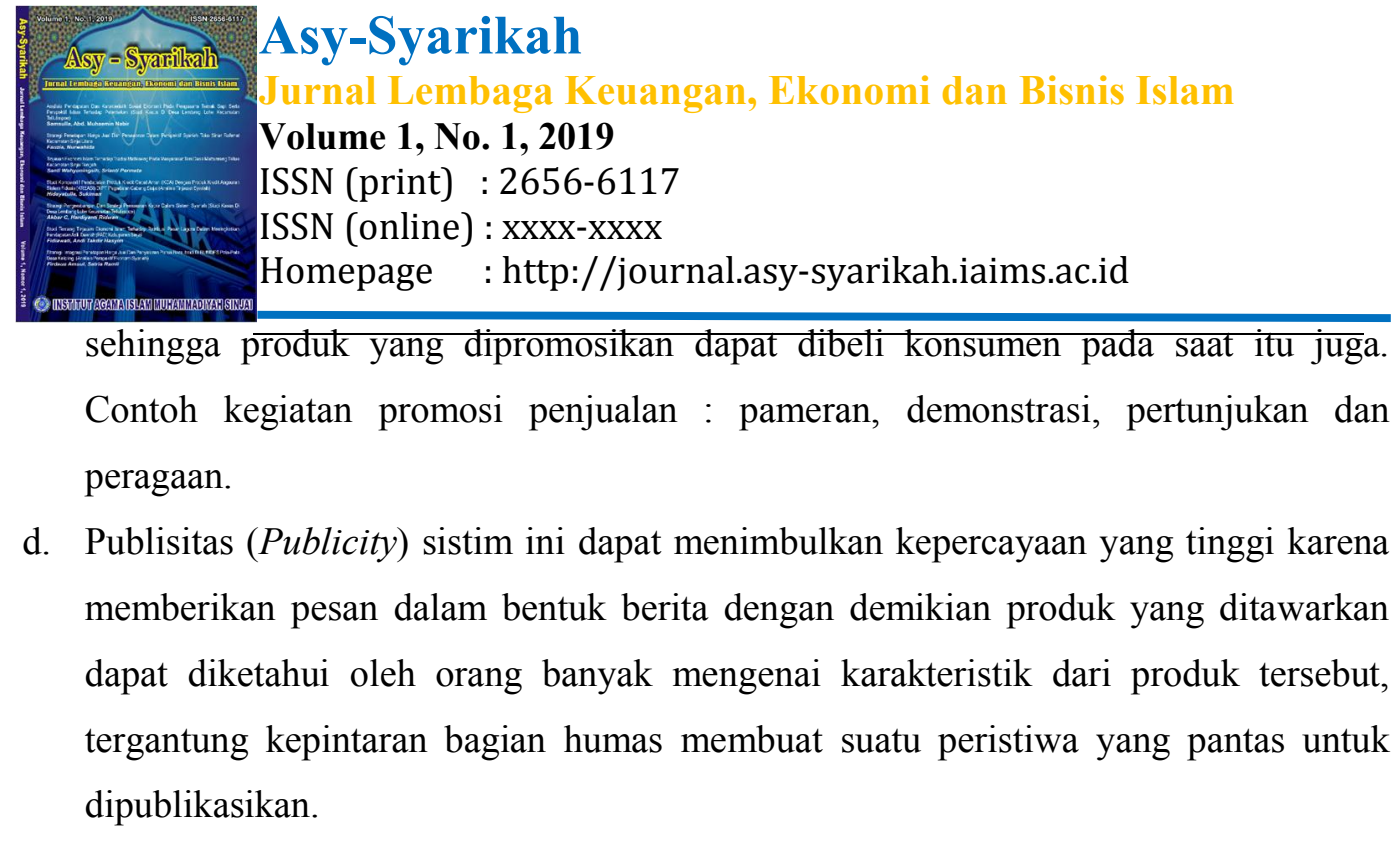

Cara lain yang efektif adalah melalui promosi dari mulut ke mulut (word of mouth) di mana satu orang memberikan penjelasan atau informasi kepada orang lain karena merasa mendapatkan manfaat yang baik dari produk atau jasa yang digunakan. Promosi ini sangat efektif karena biasanya orang lebih percaya kepada apa yang dikatakan oleh saudara ataupun teman-teman yang sudah merasakan terlebih dahulu manfaatnya. Responden A. Rosnidar mengatakan bahwa :

"Saya juga melakukan promosi serta informasi yang didapatkan oleh pembeli yang satu dengan pembeli yang lain. Sehingga, orang yang belum mengetahui tentang produk yang ada di toko ini dapat mengetahuinya melalui informasi dari orang lain.

Aktifitas promosi apapun dalam sebuah usaha tidak bisa berjalan efektif jika secara internal tidak memperhatikan faktor kualitas sebuah perusahaan. Dengan kualitas produk yang baik, ditambahkan komunikasi yang mengena, maka aktifitas perusahaan bisa berjalan dengan baik. Memahami kebutuhan dan keinginan konsumen adalah hal penting yang mempengaruhi konsumen mereka. Pengaruh konsumen memperlihatkan bagaimana sebaiknya perusahaan bersaing di pasar.

Promosi dan informasi untuk masyarakat sangat penting. Hal ini untuk menarik minat para pembeli dan untuk tetap bertahan dalam dunia usaha demi kelangsungan usahanya. Mengingat berapa pentingnya produk yang baik dimata konsumen, kegiatan promosi secara rutin dilakukan dalam dunia usaha. Kelangsungan hidup usaha merupakan salah satu tujuan dari penetapan harga jual. Telah dikemukakan pada bab 2, bahwa tujuan penetapan harga adalah sebagai berikut :

1) Untuk bertahan hidup

2) Untuk memaksimalkan laba/ untuk mendapatkan keuntungan

3) Untuk memperbanyak jumlah pelanggan

4) Pertimbangan mutu/ kualitas produk 


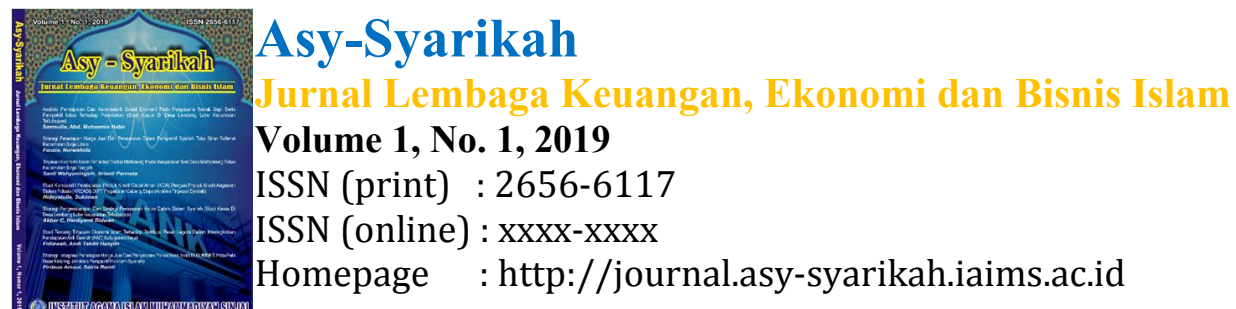

5) Karena pesaing

Sedangkan tujuan Toko Sinar Rahmat dalam menetapkan harga jual adalah untuk memperoleh penghasilan yang menguntungkan demi kelangsungan hidup usaha dan demi kelangsungan hidup keluarga. Namun yang menjadi tujuan utamanya adalah untuk mendapatkan keuntungan yang maksimal.

a. Penawaran Dalam Perspektif Syariah

Secara umum tidak terlalu banyak perbedaan antara penawaran konvensional dan penawaran dalam perspektif syariah. Satu aspek penting yang memberikan suatu perbedaan dalam perspektif ini kemungkinan berasal dari landasan filosofi dan moralitas yang didasarkan pada nilai-nilai Islam. Bahwa Islam memandang manusia secara umum, apakah sebagai konsumen atau produsen, sebagai suatu objek yang terkait dengan nilainilai. Nilai yang paling pokok yang didorong oleh islam dalam kehidupan perekonomian adalah kesederhanaan. Tidak silau dengan gemerlapnya kenikmatan duniawi dan ekonomis.

Toko Sinar Rahmat memberikan penawaran harga yang tergolong murah dari penawaran harga yang ada ditoko lain. Penawaran harga yang diberikan sekitar sekitar $20 \%$ hingga $25 \%$. Harga penawaran yang tergolong relatif murah dan tidak memberatkan antara pembeli maupun penjual atau dengan kata lain mereka sama-sama rela dan tidak ada pihak yang dirugikan merupakan suatu kesederhanaan yang merupakan nilai pokok yang dianut oleh Islam.

Toko Sinar Rahmat memberikan penawaran harga yang tergolong murah sehingga memiliki banyak pelanggan. Pelanggan yang ingin memenuhi kebutuhannya dan pemilik Toko yang menginginkan keuntungan. Namun, dalam hal ini Toko Sinar Rahmat memperkecil keuntungan. Artinya keuntungan yang didapatkan tidak terlalu banyak. Hal ini dapat dibuktikan dari cara Toko Sinar Rahmat menentukan harga jual yang relatif murah dan pemberian penawaran harga yang tidak terlalu mahal.

Hal ini diperkuat dengan pernyataan pemilik toko bahwa "saya tetap mendapatkan keuntungan namun, tidak begitu besar". Dengan kata lain keuntungan akan menjadi tambahan modal guna memperoleh mashlahah lebih besar lagi untuk mencapai falah (kesuksesan dan kemenangan dunia dan akhirat).

Menurut pemilik Toko Sinar Rahmat mengatakan bahwa :

Penawaran dalam pandangan Islam itu dilakukan dengan sewajarnya serta masuk akal dan penjual juga tidak merasa dirugikan. Atau keduanya merasa tidak ada 


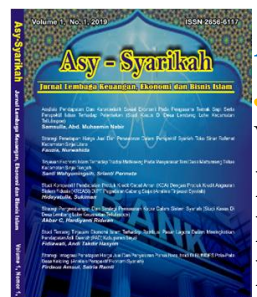

Asy-Syarikah

Jurnal Lembaga Keuangan, Ekonomi dan Bisnis Islam

Volume 1, No. 1, 2019

ISSN (print) : 2656-6117

ISSN (online) : xxxx-xxxx

Homepage : http://journal.asy-syarikah.iaims.ac.id

yang dirugikan. Intinya, penjual dan pembeli harus bersikap saling merelakan.

Kemampuan penjual dalam menyediakan barang yang akan ditawarkan kepada pembeli dan kemampuan pembeli untuk mendapatkan harga barang tersebut dari penjual. Yang pada akhirnya, penjual dan pembeli bersikap saling merelakan karena keduanya mampu memenuhi apa yang mereka inginkan.

Bahwa yang dimaksud dengan merugikan adalah melakukan sesuatu yang bermanfaat bagi dirinya, tetapi menyebabkan orang lain mendapatkan mudharat. Sedangkan yang dimaksud saling merugikan yaitu membalas orang yang merugikan kita dengan hal yang tidak setara dan tidak untuk membela kebenaran. Karena Islam dengan tegas melarang seseorang merugikan orang lain dan mengambil hak atau bagian orang lain. Sebagaimana firman Allah SWT. dalam QS. Asy-Syu'ara' (26): 183, sebagai berikut

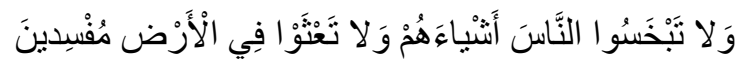

Artinya : "Dan janganlah kamu merugikan manusia dengan mengurangi hak-haknya dan janganlah membuat kerusakan dimuka bumi”.

Ayat di atas melarang untuk saling merugikan hak-hak orang lain dan membuat kerusakan dibumi, oleh karena itu dalam Islam dalam melakukan kegiatan ekonomi dituntut untuk saling menjaga hak-hak agar tidak saling merugikan antara penjual maupun pembeli.

Dalam pandangan Islam, segala transaksi yang dilakukan harus atas dasar kerelaan antara masing-masing pihak. Sebagaimana firman Allah SWT. tentang sistem jual beli yang dianut oleh Islam, dalam QS. An-Nisa (4): 29, sebagai berikut :

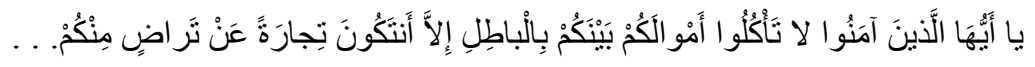

Artinya: Wahai orang-orang yang beriman! Janganlah kamu memakan harta sesamamu dengan jalan yang batil kecuali dengan jalan perniagaan yang berlaku suka sama suka diantara kamu ...

Ayat tersebut diatas menjelaskan bahwa, manusia tidak boleh memakan harta sesamanya dengan jalan yang tidak benar kecuali dengan jalan perdagangan atas dasar suka sama suka antara kedua belah pihak (rela).

Rasulullah SAW. juga bersabda :

Dari Abu Sa'id Al-Khudri berkata: Rasulullah SAW. bersabda "Sesungguhnya jual beli itu atas dasar suka sama suka." 


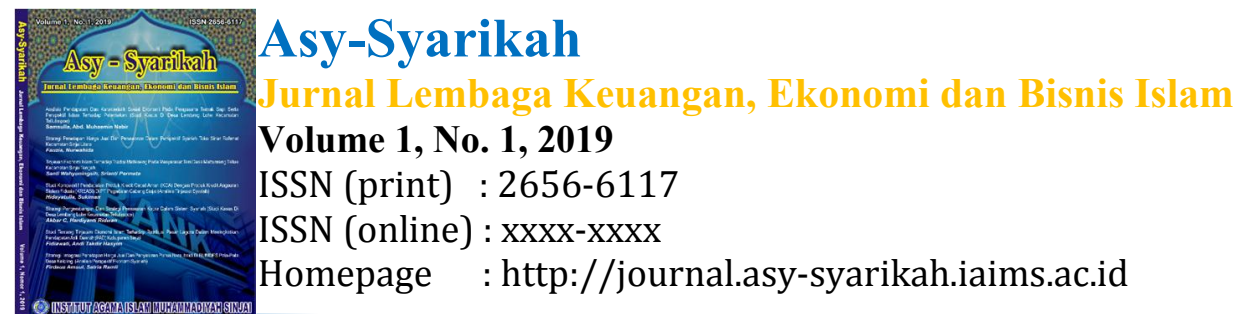

Hadist tersebut diatas diriwayatkan oleh Ibnu Majah 2/737 no: 2185 dari jalan Abu

Said Al-Khudri. Berkata Al Bushiri dalam Az-Zawaid: Sanadnya shohih dan para parowinya terpercaya, juga dishohihlan oleh Syaikh Al-Bani dalam Shohih Ibnu Majah: 1792 dan Irwa: 1283.

Dalam perspektif ekonomi Islam, manusia diinjeksi dengan norma moral Islam sehingga nafsu untuk memenuhi keinginannya tidak selalu dipenuhi. Karena, keinginan senantiasa dikaitkan dengan norma moral Islam yang selalu menemaninya kemana saja dan dimana saja. Karena itu, semua barang yang ditawarkan mencerminkan kebutuhan sesuai dengan syariah itu sendiri.

Oleh karena itu, Toko Sinar Rahmat selain memberikan penawaran harga yang relatif murah, juga selalu menjaga hubungan baik dengan pelanggan atau pembeli.Menurut penulis hubungan antara sistem jual beli secara konvensional dan sistem jual beli menurut syariat islam adalah sama-sama melakukan transaksi jual beli dan samasama mendapatkan keuntungan dari proses transaksi tersebut. Namun, jika dilihat dari segi konvensionalnya keuntungan yang diperoleh lebih besar dibandingkan sistem jual beli yang dilakukan berdasarkan syariat Islam.

\section{Daftar Pustaka}

Abdullah, Thamrin\&Francis Tantri. Manajemen Pemasaran, Cet. IV; Jakarta: Rajawali Pers, 2005.

Ahmadi, Rulam. Metodologi Penelitian Kualitatif, Cet. III; Yogyakarta: Ar-Ruzz Media, 2016.

Departemen Agama RI, Al-Qur'an dan Terjemahnya, Cet. I; Bandung: Yayasan Penyelenggara Penerjemah/Penafsir Al-Qur'an, 2007.

Dewantoro, Sukarno. "Strategi Penetapan Harga Pada PT Madubaru Bantul”, Skripsi, Yogyakarta: Universitas Negeri Yogyakarta, 2015.

Fita Aryani. (2016). Konsep Pendapatan (Teori Akuntansi). [Blog]. http://fitaaryani.blogspot.com, Diakses pada tanggal 8 Agustus 2017.

Ghazaly, Abdul Rahman dkk. Fiqh Muamalat, Cet. I; Jakarta: Prenadamedia Group, 2010. 


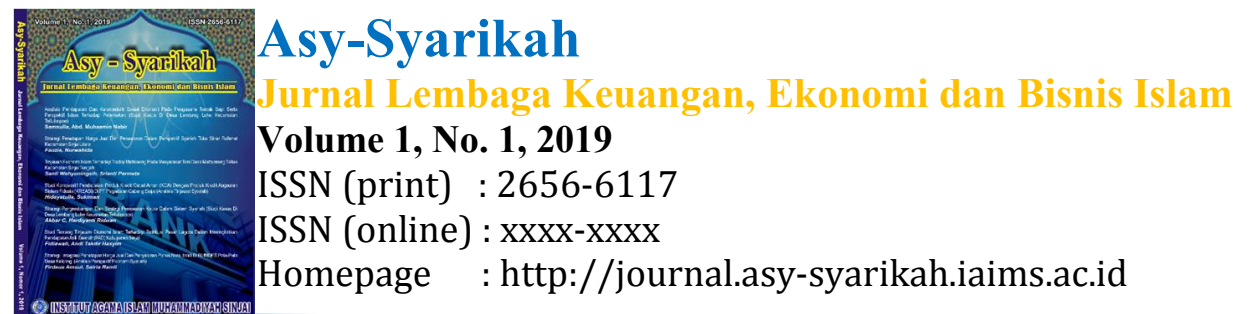

Ghony, Djunaidi \& Fauzan Almanshur. Metode Penelitian Kualitatif, Cet. III; Jogyakarta: Ar-Ruzz Media, 2016.

Gunawan, Imam. Metode Penelitian Kualitatif: Teori dan Praktik, Cet. IV; Jakarta: Bumi Aksara, 2016.

Hakim, Lukman. Prinsip-Prinsip Ekonomi Islam, Cet. XV; Bandung: Erlangga, 2012.

Hartono,Toni. Mekanisme Ekonomi Dalam Konteks Ekonomi Indonesia, Cet. I; Bandung: Remaja Rosdakarya, 2006.

Hendro. Dasar-Dasar Kewirausahaan, Cet. I; Jakarta: Erlangga, 2011.

Kasmir. Kewirausahaan, Cet. IX; Jakarta: Rajawali Pers, 2013.

Ladlul Muksinin, (2015), Teori Harga Dalam Islam. Data dikutip dari http://pustakamediasyariah.blogspot. com., diakses pada tanggal 15 Agustus 2017.

Narbuko, Cholid dan Abu Achmadi. Metodologi Penelitian, Cet. XIII; Jakarta: Bumi Aksara, 2013.

Nur Aisyah, Sovi. “Analisis Mekanisme Penetapan Harga Jual Dalam Perspektif Prinsip-Prinsip Ekonomi Syariah", Skripsi, Cirebon: IAIN Syekh Nurjati Cirebon, 2015.

Pengertian Harga Jual dan Metode Menentukan Harga Jual. [Blog]. http://jalurbaru.blogspot.com, Diakses pada tanggal 3 Agustus 2017.

Prastowo, Andi. Metode Penelitian Kualitatif: Dalam Perspektif Rancangan Penelitian, Cet. III: Jogyakarta: Ar-Ruzz Media, 2016.

Siddiqi, Muhammad Nejatullah. Kegiatan Ekonomi Dalam Islam, Cet. III; Jakarta: Bumi Aksara, 2004.

Sugiyono. Metode Penelitian Kuantitatif, Kualitatif, dan R\&D, Cet. XXV; Bandung: Alfabeta, 2017.

Suhendi, Hendi. Fiqhi Muamalah, Cet. IX; Jakarta: Rajawali Pers, 2014. 


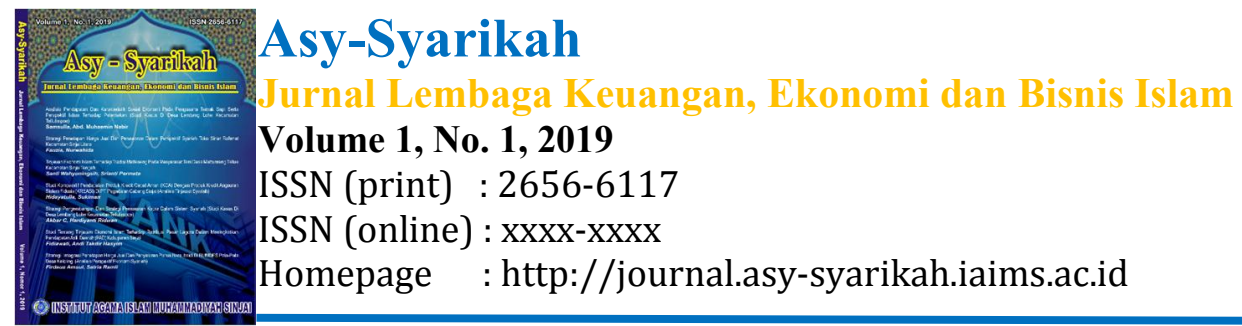

Syarifuddin, Amir. Garis-Garis Besar Fiqh, Cet. I; Jakarta: Kencana Prenadamedia Group, 2003.

Zuriah, Nurul. Metodologi Penelitian Sosial dan Pendidikan, Cet. III; Jakarta: Sinar Grafika Offset, 2009. 